\title{
Bacevic, Jana (2014). From Class to Identity / The Politics of Education Reforms in Former Yugoslavia. Budapest - New York: CEU press, 235 pp. ISBN 978- 615-5225-72-7.
}

Reviewed by DARKo ŠTrAJN ${ }^{1}$

Many questions about the reasons for the incredibly violent collapse of the Socialist Federal Republic of Yugoslavia remain unanswered, and probably the 'deepest' of them will never be sufficiently answered. However, thanks not only to the passage of time but also due to slowly accumulating research in different venues of the social sciences and humanities, growing numbers of increasingly convincing interpretations of the historic events and more reliable theories of the social, ethnic, cultural and, above all, political backgrounds are making progress in providing answers. It would be pretentious to say that Yugoslavia serves as an ultimate historical lesson for the future, and it would be overly optimistic to expect that anyone learned their 'lesson', but it is clear now that the Yugoslav example has informed theoretical thinking, and influenced a formation of conceptual constructions concerning topics such as social conflicts, political actors, ideologies and so on. Jana Bacevic's book inscribes itself into this conceptual space with one of the most consistent and clarifying interdisciplinary insights into the structures, processes and twisted logics of the Yugoslav episode in recent European history. The fact that the book is focused on and by education contributes much to the precision of hypotheses and assumptions in the book. At the same time, such a perspective proves to be especially rewarding as it enables the author to dispense with the abundance of clichés, simplifications and other more or less ideologically fashioned 'explanations' of the deplorable end of what once seemed as a promising large-scale political project. Jana Bacevic also clearly demonstrates that taking a view on a society through its central institutional instrument of reproduction is precisely that point of departure, which triggers an eruption of a number of crucial questions on how we understand and interpret a society and especially its conflicts. One such crucial problem is formulated at the beginning of the book: 'The fact that a country with high levels of education managed to disintegrate in a violent conflict strongly challenges the assumption about the preventive nature of

1 Educational Research Institute (Pedagoški inštitut), Ljubljana, Slovenia; darko.strajn@guest. arnes.si 
education in terms of managing social cleavages' (p. 6). The author later dispels a whole signifying chain of established explanations and accounts of the Yugoslav tragedy, from references to the 'ancient ethnic hatreds' to a number of emphases on 'cultural differences' as presumable reasons for the conflict. However, the book is not merely about dispelling wrong assumptions, but is a nuanced study of the policies and trends in Yugoslav education before and after the war.

The Introduction is the first chapter of this admirable study. It is followed by four chapters, which are organised around conceptual core notions as well as around some important historical and institutional issues in the processes. Of course, the Introduction appropriately explains the structure of the book, giving an overview of the research methods and main topics of the book, but it also puts forward many ingenious hypotheses and assumptions. Hence, an interested reader receives a strong incentive to read the entire book through to the end. As I suggested in the first paragraph of my review, Bacevic's postulations in the first chapter build on the Yugoslav experience in order to reformulate a good part of the entire field of education studies. She shows very convincingly that some widely accepted assumptions of a role of education simply do not work, whole simultaneously demonstrating that there is more complex interaction between education, policies and politics, which through political subjectivities and group identities enter social processes. On the bases of such insights, Bacevic makes no secret of her conclusive assertion that the Yugoslav case transcends its particular significance, and it instigates somewhat renewed theories on the role of education policies in different contexts.

Chapter 2 contains an interpretative and explanatory account of the Yugoslav education reform, which Bacevic choses to name 'vocationalizing education.' The reform, which started in the 1970s, was based on the rhetoric of class, but failed due to multifarious opposition against its different features. Bacevic does not say so, but one could see similarities between the language of the last Yugoslav education reform and the rhetoric of competencies, skills and abilities, which permeates the discourse of education reform in the marketoriented Europe. The latter only replaces class-related notions, which signify the social context, with a chain of other notions as for instance employability, competitivity, human resources and so on. However, the author makes clear that the Yugoslav education reform was interlaced with politics, which led to the final social conflicts. To further explain this historic structure, she gives a well-informed view on the social movements and events that affected the cohesion in the former Yugoslavia. It is a very telling fact that serious mass dissent erupted in university centres in most constitutive republics of Yugoslavia, but in each of them for quite different reasons. In her analysis, Bacevic arrives 
at the conclusion that the education reform's 'primary driver was ideological rather than economic' (p. 74). She clearly points out that the education processes should be read against the background of political developments as, for instance, a noteworthy constitutional reform in 1974, which was an attempt to contain looming 'national' (meaning also 'ethnic') conflicts of 1980s and 199os.

For well-founded reasons, the next chapter concentrates on a clash between religious education and what the author amusingly names 'civic EUcation.' The chapter is focused on (Milošević's) Serbia, the largest former Yugoslav Republic and political developments there, compared to what had been going on in other former Republics, now independent states. Bacevic's reading of different genres of politically motivated narratives exposes the identitarian trend, which produced a centrality of the 'problem' of civic and/or religious education. Of course, the religious education has to do with historical and cultural traditions in the ideological core of the politics that constructs invented traditions.

Chapter 4 deals with higher education and with post-conflict development, primarily in the Serb province of Sandžak and in semi-recognized states of Kosovo and Macedonia. The author asserts that 'the countries of former Yugoslavia eagerly joined the [Bologna] process' (p. 126). Hence, she determines that Bologna reform is as a policy considered to be a part of 'Europeanization' in most of these countries. She shows an interesting phenomenon of 'two in one', meaning that in many multi-ethnic cities two universities, instead of one, were established to reflect the ethnic divides. She then goes on to the case of Kosovo, which 'represents the clearest case of intersection between education policies and identity politics' (p. 136). The struggle in the framework of education policies in Kosovo, as one can surmise from the author's writing, serves as an explanatory instance for the whole process of disintegration of Yugoslavia. This part of the book brings forward many interesting clarifications and a great deal of information on events that led to the contemporary as-ever ambiguous and unstable social situation, although in substantially changed political framework. Especially for those readers who are not acquainted with the complicated construction of former Yugoslavia, a part of this chapter on the Muslim-inhabited region of Sandžak, is very interesting and it explains much. The struggle between different 'identities' is evolving through higher education institutions. Another case is Macedonia, where the 'two in one' phenomena is also rampant, only in this case main actors are ethnic Macedonians and ethnic Albanians. Bacevic points also to some praiseworthy attempts to overcome ethnic cleavages, for instance, in the case of South East European University (established in 2001), where they attempted to introduce trilingualism (Macedonian, Albanian and English). With substantial international support, the experiment overcame opposition from both sides. 
The concluding chapter is built around Theodor Adorno's view on the necessity of ensuring that Auschwitz never happens again. On the bases of her study of the role of education in the countries of former Yugoslavia, Jana Bacevic claims that neither emancipatory nor reproductive education exist. She supports her finding with Adorno and other critical theorists, who 'considered that the totalizing, violent potential of education did not emanate from the practice itself, but rather from the tendency of education to reflect and reproduce the prevailing ethos of society' (p. 211). Bacevic here clearly points out that the problematic relationships between education, policies and politics concerns not only the former Yugoslavia. She admits that there are, due to its relative autonomy, 'potentials in education' for at least generating critical voices and that subsequently 'education can actually serve as a consistently progressive social force' (p. 211).

Finally, the book should be applauded for its perceptive theoretical discourse and well-founded conclusions, but it is also interesting for all those readers who would like more details on what has been happening in the region of the Balkans. Jana Bacevic gives a very good overview of historical events, explains the logics of the development towards politics of identity that followed decades of the communist stress on class politics and, above all, makes a reader understand how education can work for different goals in conjunction with social forces. 